\title{
Effect of pepsin hydrolysis on antioxidant activity of jellyfish protein hydrolysate
}

\author{
Pratchaya Muangrod ${ }^{1}$, Wiriya Charoenchokpanich ${ }^{1}$, Vilai Rungsardthong $^{1}$, Savitri Vatanyoopaisarn $^{1}$, Benjamaporn \\ Wonganu $^{2}$, Sittiruk Roytrakul ${ }^{3}$ and Benjawan Thumthanaruk ${ }^{1, *}$ \\ ${ }^{1}$ Department of Agro-Industrial Food and Environmental Technology, Faculty of Applied Science, King Mongkut's University of \\ Technology North Bangkok, Bangkok, Thailand \\ ${ }^{2}$ Department of Biotechnology, Faculty of Applied Science, King Mongkut's University of Technology North Bangkok, Bangkok, \\ Thailand \\ ${ }^{3}$ National Center for Genetic Engineering and Biotechnology, National Science and Technology Development Agency (NSTDA), \\ Pathum Thani, Thailand
}

\begin{abstract}
Edible jellyfish have been consumed as food for more than a century with offering high protein and crunchy texture. The pepsin hydrolysis of jellyfish protein yields jellyfish protein hydrolysate (ep-JPH), reported for potential bioactivities such as antioxidant activity or antihypertensive activities. Due to the substantial number of by-products generated from jellyfish processing, the by-products were then selected as a raw material of JPH production. This research aimed to evaluate the effect of the hydrolysis time of pepsin on the antioxidant activity of ep-JPH. The dried desalted jellyfish by-products powder was enzymatically hydrolysed by $5 \%(\mathrm{w} / \mathrm{w})$ pepsin, and the hydrolysis time was varied from $6,12,18$, and $24 \mathrm{~h}$ at $37^{\circ} \mathrm{C}$. Results showed that increased hydrolysis time increased the degree of hydrolysis (DH) and inhibition of DPPH radical. The $24 \mathrm{~h}$ ep-JPH possessed the highest DH and the highest inhibitory effect of DPPH radical. The results demonstrated that, in this experiment, all ep-JPHs were DPPH radical scavengers, exhibiting different inhibition activities depending on DH values.
\end{abstract}

Keyword. Salted jellyfish by-products, Protein hydrolysate, DPPH, Degree of hydrolysis

\section{Introduction}

Protein hydrolysates are products of protein degradation that yield various sizes of peptides and free amino acids $[1,2]$. There are several methods of protein hydrolysate production, including acids or alkali hydrolysis and enzymatic hydrolysis [1-3]. Different methods of protein hydrolysate production result in different bioactivity of protein hydrolysate due to its amino acid composition and sequence $[1,4,5]$.

Enzymatic hydrolysis is one of the practical protein hydrolysate productions via protease enzymes that cleave specific peptide bonds and provide short peptides with small molecular weights [1]. Most low molecular weight enzymatic hydrolysate peptides containing approximately 2-20 amino acid residues are considered bioactive peptides $[5,6]$. Commercial proteases are practically used for protein hydrolyses, such as trypsin, pepsin, collagenase, alcalase, papain, and bromelain [7, 8]. Different types of protease enzymes also provided different bioactive peptides.

To date, the different sources of food proteins for producing bioactive peptides are meat $[9,10]$, milk $[11-$ 13], eggs [14, 15], nuts [16], cocoa bean [17], beef [18], pork [18], chicken [18], turkey [18], and fish [19]. Factors of type of protease enzymes, hydrolysis time, and raw material factors used for peptide production yield different amino acid compositions and amino acid sequences [20-23], which offer different bioactive activities such as antioxidant, anticancer, antimicrobial, and antihypertensive [3, 24, 25]. Antioxidant activity, the ability to reduce or scavenge free radicals, is one of the major biological activities of protein hydrolysates that have mostly been reported [3]. If the number of free radicals exceeds normal, free radicals can cause diseases such as arthritis, diabetes, atherosclerosis, ageing, and cancer $[8,26]$. Then, the novel protein sources of bioactive peptides having antioxidant activities are currently of interest for reducing the risk of various diseases [26]. The marine source has become attractive with various organisms that have potentially been reported for biological activities. Edible salted jellyfish, the oldest marine plankton consumed for more than a century by Chinese people, is selected to produce jellyfish protein hydrolysate (JPH). Apart from water content in the body, jellyfish are considered high protein food, mainly collagen [27, 28]. Few jellyfish species used for producing JPH have been reported for antioxidant activities $[6,8,24]$. No antioxidant activity of protein hydrolysate from jellyfish (Lobonema smithii) hydrolysed with pepsin has not been studied. Therefore, the by-products of salted jellyfish from salted jellyfish processing were selected for producing hydrolysate by pepsin hydrolysis (ep-JPH). The research aimed to

Corresponding author: benjawan.t@sci.kmutnb.ac.th 
evaluate the effect of the hydrolysis time of pepsin on the antioxidant activity of JPH.

\section{Materials and methods}

\subsection{Preparation of salted jellyfish by-products}

The broken pieces or irregular shapes of jellyfish (Lobonema smithii) sold as by-products were kindly received from Chockdee Sea Products Co., Ltd., Samut Songkhram, Thailand. Due to the high salt in jellyfish by-products, washing and drying were used to prepare the raw material as previously described [27, 29]. First, the washing of salted jellyfish by-products with tap water at a ratio of 1:40 (w/v) was performed by a rotational jellyfish washing machine for 2 cycles, and 15 min per cycle and drained for $30 \mathrm{~min}$. The desalted jellyfish by-products were dried in a tray dryer (ED 400, Binder, USA) at $60^{\circ} \mathrm{C}$ for $24 \mathrm{~h}$ and then ground into fine particles and filtered through a sieve of size 100 mesh. The jellyfish protein powder (JPP) was analyzed for the chemical compositions (moisture, protein, fat, and ash content) before use (Fig. 1). The powder was packed in sealed PE bags and kept at room temperature until use.

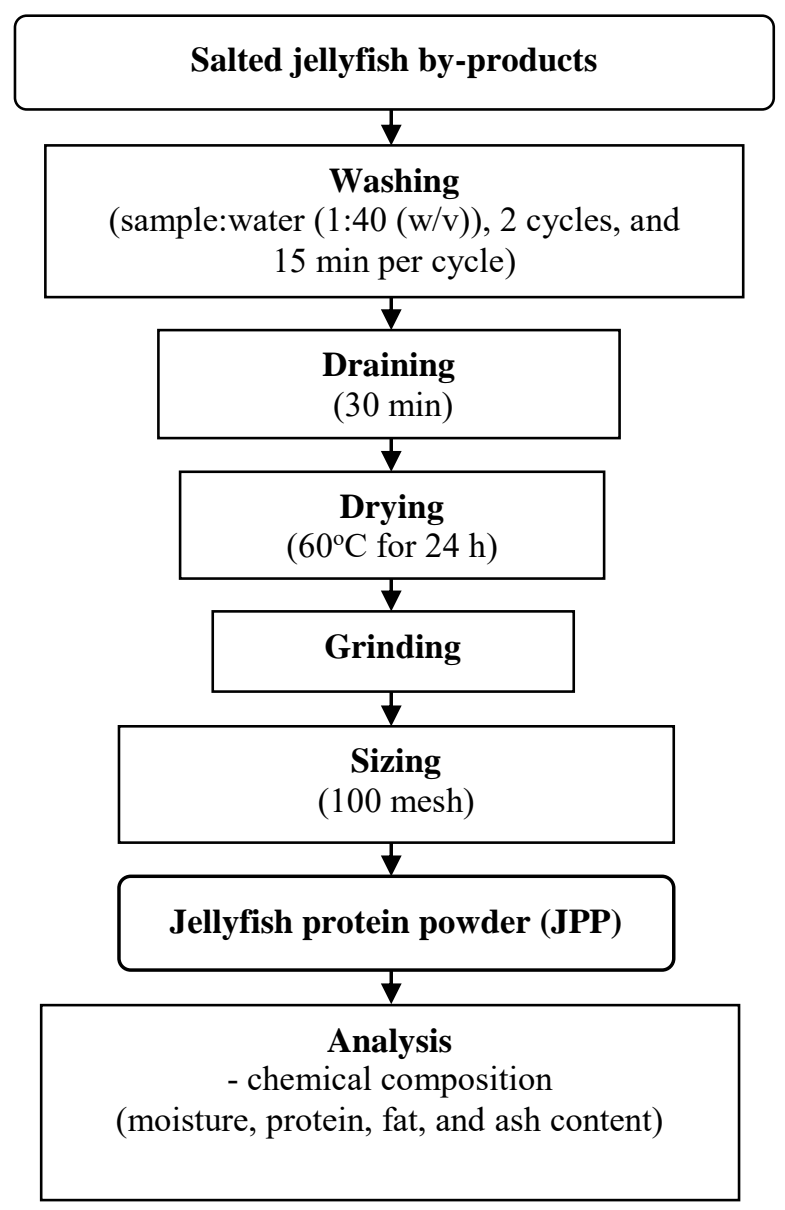

Fig. 1. Preparation of salted jellyfish by-products (JPP).

\subsection{Preparation of jellyfish protein hydrolysate (JPH)}

JPH was prepared as previously described [30, 31] with a slight modification (Fig. 2). Briefly, JPP was mixed in $0.05 \mathrm{M}$ sodium acetate buffer at the ratio of 1: $25 \mathrm{w} / \mathrm{v}$ $(4 \mathrm{~g} / 100 \mathrm{~mL})$ at $95^{\circ} \mathrm{C}$ for $10 \mathrm{~min}$ to inactivate the endogenous enzymes and then equilibrated to the optimum temperature conditions. Next, the sample was dissolved in $0.05 \mathrm{M}$ sodium acetate buffer at the ratio of enzyme: substrate (1: $20 \mathrm{~g}$ : g; w/w). Then, the mixture was hydrolysed by pepsin at $37^{\circ} \mathrm{C}$ for $6,12,18$, and $24 \mathrm{~h}$ using a shaking incubator (WIS-20R, WiseCube, Korea) at $150 \mathrm{rpm}$. After that, the enzyme was inactivated by heating at $95^{\circ} \mathrm{C}$ for $10 \mathrm{~min}$ in a temperature-controlled water bath shaker (Memmert, Schwabach, Germany) at $100 \mathrm{rpm}$. Next, the hydrolysate was centrifuged at 9,500 $\times \mathrm{g}$ for $10 \mathrm{~min}$. Finally, the supernatant of ep-JPH was filtered by Whatman filter paper No1. The samples were stored at $-18^{\circ} \mathrm{C}$ until further analysis.

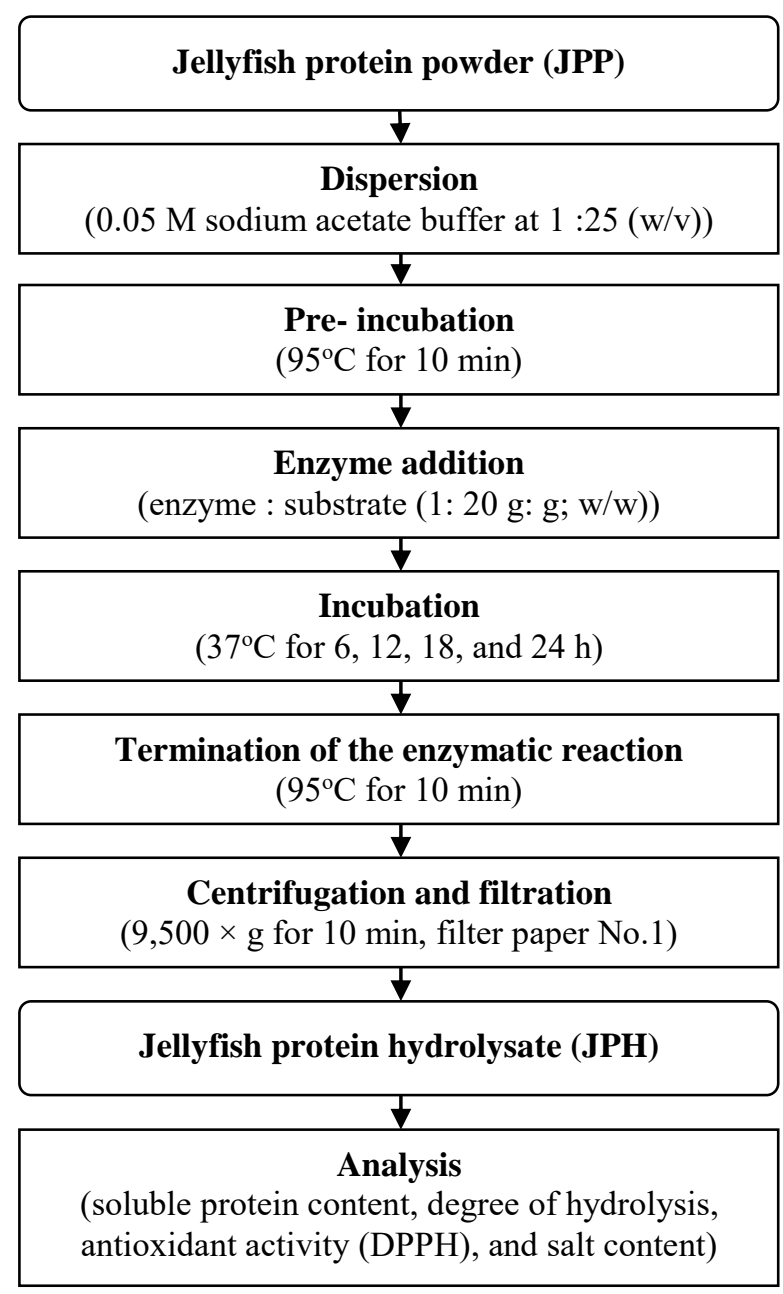

Fig. 2. Preparation of jellyfish protein hydrolysate (JPH)

\subsection{Analysis}

\subsubsection{Chemical composition}

The proximate composition of JPP including, moisture, protein, fat, and ash content, was measured according to 
the AOAC standard methods [32]. The protein content was measured using the Kjeldahl method. A factor of 5.55 was used to convert the nitrogen value to protein [33].

\subsubsection{Soluble protein content}

The soluble protein content of JPH was determined according to the Lowry method [34]. Bovine serum albumin was used as a standard.

\subsubsection{Degree of hydrolysis}

The analysis of DH was slightly modified by the method of trinitrobenzyl sulfonic acid (TNBS) [35]. Briefly, a $125 \mu \mathrm{L}$ of jellyfish protein hydrolysate was mixed with 2 $\mathrm{mL}$ of phosphate buffer $(\mathrm{pH} 8.2$ ) and $1 \mathrm{~mL}$ of $0.01 \%$ TNBS reagent. Then, the mixture solution was incubated at $50^{\circ} \mathrm{C}$ for $30 \mathrm{~min}$ in the dark using a temperaturecontrolled water bath (WNB 45, Memmert, Germany). The reaction was stopped by adding $2 \mathrm{~mL}$ of $0.1 \mathrm{M}$ sodium sulfite and incubated at room temperature for 15 min. The absorbance was measured at $420 \mathrm{~nm}$ using a spectrophotometer (SP 830 plus, Metertech, Taiwan). The DH was calculated according to the following equation (1):

$$
D H(\%)=\left[\left(L-L_{0}\right) /\left(L_{\max }-L_{0}\right)\right] \times 100
$$

where $\mathrm{L}=$ The amount of $\alpha$-amino groups of hydrolysate sample, $\mathrm{L}_{0}=$ The amount of $\alpha$-amino groups in the original substrate (blank), and $\mathrm{L}_{\max }=$ The total $\alpha$-amino groups in the sample hydrolysed by $6 \mathrm{~N} \mathrm{HCl}$ at $100^{\circ} \mathrm{C}$ for $24 \mathrm{~h}$.

\subsubsection{Antioxidant activity (DPPH radical scavenging assay)}

DPPH radical scavenging activity was analyzed as previously described $[26,36]$ with slight modifications. A $0.1 \mathrm{~mL}$ of $\mathrm{JPH}$ was mixed with $1.9 \mathrm{~mL}$ of 0.15 $\mathrm{mmol} / \mathrm{L} \mathrm{DPPH}$ in $70 \%$ ethanol. The mixture was then incubated in the dark for $30 \mathrm{~min}$ at room temperature. The absorbance was measured at $517 \mathrm{~nm}$ using a spectrophotometer (SP 830 plus, Metertech, Taiwan). In this measurement, ascorbic acid was a positive control. The inhibition of DPPH radical scavenging activity was calculated by the following equation (2):

$$
\% \text { inhibition }=\left[\left(A_{\text {control }}-A_{\text {sample }}\right) / A_{\text {control }}\right] \times 100
$$

where $\mathrm{A}_{\text {control }}$ is the absorbance of the control that contained all reagents except the test samples. $A_{\text {sample }}$ is the absorbance of the JPH with reagents added.

\subsubsection{Salt content}

The salt content of jellyfish protein hydrolysate referred to the percentage of sodium chloride $(\mathrm{NaCl})$ in $\mathrm{JPH}$ was determined using a conductivity meter (TDS Meter 308, Systronics, India). The percentage of sodium chloride in JPH was predicted from the standard curve.

\subsection{Statistical analysis}

All experiments were performed in triplicate. Results were shown as mean \pm standard deviations. The data were subjected to analysis of variance (ANOVA), and Duncan's multiple range test was used to measure the significant difference $(\mathrm{p}<0.05)$ using the statistical package for social science (SPSS) 22.0.

\section{Results and discussions}

\subsection{Quality of jellyfish protein powder}

The jellyfish protein powder (JPP) had moisture, protein, fat, and ash content of $7.42 \pm 0.20 \%, 76.59 \pm 0.11 \%$, $1.32 \pm 0.05 \%$, and $15.54 \pm 0.36 \%$, respectively. Results of proximate composition of JPP were similar to the previous study that JPP had $7.69 \%, 76.41 \%, 1.35 \%$, and $15.76 \%$, respectively [27], but slightly different from the work of Emrerk et al. (2021) [37], who reported that JPP had $5.27 \%, 68.8 \%, 3.18 \%$, and $9.11 \%$, respectively. Therefore, according to the high protein content, the JPP was selected for producing jellyfish protein hydrolysate.

\subsection{Effect of hydrolysis time of pepsin on soluble protein content, degree of hydrolysis, antioxidant activity (DPPH), and salt content of jellyfish protein hydrolysate (JPH)}

Pepsin is an aspartic protease that has an optimum $\mathrm{pH}$ of 1.8. Pepsin hydrolyzes peptide bonds between large hydrophobic amino acid residues and yields peptides. Table 1 shows the soluble protein content of enzymatic pepsin hydrolysed JPH (ep-JPH) for different hydrolysis times $(6,12,18$, and $24 \mathrm{~h})$ at $37^{\circ} \mathrm{C}$. Increased hydrolysis time of pepsin increased soluble protein content of epJPH. The soluble protein contents of ep-JPH derived from $6,12,18$, and $24 \mathrm{~h}$ were $1,428.47,1,461.25$, 1,491.80, and 1,589.30 mg/L, respectively. During the hydrolysis process, jellyfish collagen protein was denatured by pepsin and acidic conditions. As a result, the jellyfish protein was hydrolysed, thus generating the soluble proteins.

$\mathrm{DH}$ is a parameter used for determining how well the pepsin hydrolysed jellyfish protein. In this experiment, increased hydrolysis time of pepsin increased the values of $\mathrm{DH}$. The hydrolysis condition of ep-JPH for $6,12,18$, and $24 \mathrm{~h}$ showed the DH values of $52.20 \%, 54.01 \%, 54.50 \%$, and $55.41 \%$ (Table 1). During the pepsin hydrolysis, the peptide bonds of a jellyfish protein were hydrolysed and provided a short-chain peptide and free amino acid [38], depending on hydrolysis factors, including pepsin concentration, hydrolysis time, and temperature. In this study, the pepsin hydrolysed jellyfish sample at the hydrolysis time of $12,18,24 \mathrm{~h}$ showed similar $\mathrm{DH}$ values, and these values were not significantly different. The DH results were similar to the previous studies that hydrolysed jellyfish protein with bromelain at $50^{\circ} \mathrm{C}$ for $18 \mathrm{~h}$ and trypsin at $50^{\circ} \mathrm{C}$ for $9 \mathrm{~h}[8,37]$. Thus, the soluble protein and $\mathrm{DH}$ values are affected by pepsin hydrolysis. In this 
study, the pepsin hydrolysis for $24 \mathrm{~h}$ at $37^{\circ} \mathrm{C}$ was sufficient for producing ep-JPH.

Table 1. Soluble protein content and degree of hydrolysis of enzymatic pepsin-jellyfish protein hydrolysate (ep-JPH) at different hydrolysis times.

\begin{tabular}{|c|c|c|}
\hline Sample & $\begin{array}{c}\text { Soluble protein } \\
\text { content* }(\mathrm{mg} / \mathrm{mL})\end{array}$ & $\begin{array}{c}\text { Degree of } \\
\text { hydrolysis* (\%) }\end{array}$ \\
\hline ep-JPH 6 h & $1,428.47 \pm 21.75^{\mathrm{c}}$ & $52.20 \pm 0.53^{\mathrm{d}}$ \\
\hline ep-JPH 12 h & $1,461.25 \pm 12.27^{\mathrm{bc}}$ & $54.01 \pm 0.07^{\mathrm{c}}$ \\
\hline ep-JPH $18 \mathrm{~h}$ & $1,491.80 \pm 23.48^{b}$ & $54.50 \pm 0.10^{\mathrm{b}}$ \\
\hline ep-JPH 24 h & $1,589.30 \pm 51.14^{\mathrm{a}}$ & $55.41 \pm 0.10^{\mathrm{a}}$ \\
\hline
\end{tabular}

*Different superscripts $(\mathrm{a}, \mathrm{b}, \mathrm{c}, \mathrm{d})$ in the same column mean significant difference in value $(\mathrm{p}<0.05)$

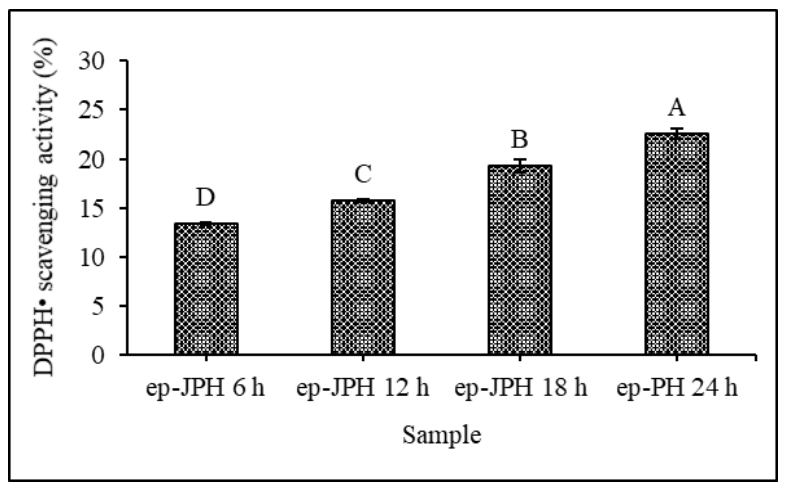

Fig. 3. DPPH radical scavenging activity (\%) of jellyfish protein hydrolysate $(\mathrm{JPH})$ at different duration times of hydrolysis $(6,12,18$, and $24 \mathrm{~h})$; bars with the different superscripts were significantly different $(\mathrm{p}<0.05)$.

DPPH is an organic nitrogen radical that shows maximal absorbance at $517 \mathrm{~nm}$ in ethanol when DPPH encounters a protein donating substance that is an indicator of the antioxidant capacity of the sample [6, 39]. Results showed increased pepsin hydrolysis time of JPH increased \% inhibition of DPPH radical scavenging activity. The inhibition values of DPPH radical scavenging activity by ep-JPHs obtained from $6,12,18$, and $24 \mathrm{~h}$ of hydrolysis were $13.38 \pm 0.07 \%, 15.73 \pm 0.13 \%$, $19.31 \pm 0.66 \%$, and $22.56 \pm 0.51 \%$, respectively (Fig. 3). Results of DPPH radical scavenging activity of ep-JPH were slightly different from that value of trypsin hydrolysed ribbon jellyfish (Chrysaora sp.) for $7 \mathrm{~h}$, approximately $25 \%$ [8]. The factors that affected the antioxidant activity of protein hydrolysate are highly dependent on hydrolysis condition (temperature and duration time), sequence and amino acid composition, and protease enzyme (types and concentration) [6]. Thus, in this study, all ep-JPHs were able to scavenge DPPH radicals, and the $24 \mathrm{~h}$ ep-JPH showed the highest inhibition effect on DPPH radicals.

Results of DPPH radical scavenging activity were correlated with the results of $\mathrm{DH}$. The small peptides generated by pepsin hydrolysis may donate electrons to DPPH radical, thereby reducing free radical action [6].
Thus, the highest DH value showed the highest inhibition of the DPPH radical. Previous research has reported that short-chain peptides containing 2 to 20 amino acids may positively impact health [17]. Therefore, the amino acid sequence of ep-JPHs is needed for further analysis.

The conductivity values measuring the salt ion content of ep-JPH increased as pepsin hydrolysis time increased, as shown in Table 2 . The conductivity values of ep-JPH at different hydrolysis times were 1,853.33, 1,894.67, 1,960.67, and 1,997.00 $\mu \mathrm{s} / \mathrm{cm}$, respectively. All JPH samples presented a salt content of approximately $0.09 \%$. Results also related to the previous work that the salt content of enzymatic bromelain-JPH at $50^{\circ} \mathrm{C}$ for $6-18 \mathrm{~h}$ were $1.50-2.22 \%$ [37]. Despite desalted jellyfish used, the salt content that remained in the solution must be removed to prevent the interferences of electrophoresis or LC-MS/MS analysis in the future.

Table 2. Salt content of enzymatic pepsin-jellyfish protein hydrolysate (ep-JPH) at different hydrolysis times.

\begin{tabular}{|c|c|c|}
\hline Sample & $\begin{array}{c}\text { Conductivity* } \\
(\mu \mathrm{s} / \mathrm{cm})\end{array}$ & Salt content* $(\%)$ \\
\hline ep-JPH 6 h & $1,853.33 \pm 1.52^{\mathrm{d}}$ & $0.090 \pm 0.00^{\mathrm{d}}$ \\
\hline ep-JPH 12 h & $1,894.66 \pm 1.52^{\mathrm{c}}$ & $0.092 \pm 0.00^{\mathrm{c}}$ \\
\hline ep-JPH 18 h & $1,960.66 \pm 7.02^{\mathrm{b}}$ & $0.096 \pm 0.00^{\mathrm{b}}$ \\
\hline ep-JPH 24 h & $1,997.00 \pm 2.64^{\mathrm{a}}$ & $0.098 \pm 0.00^{\mathrm{a}}$ \\
\hline
\end{tabular}

*Different superscripts $(\mathrm{a}, \mathrm{b}, \mathrm{c}, \mathrm{d})$ in the same column mean significant difference in value $(p<0.05)$

\section{Conclusion}

The $24 \mathrm{~h}$ ep-JPH at $37^{\circ} \mathrm{C}$ showed the highest soluble protein content, $\% \mathrm{DH}$, and \%inhibition of DPPH radical. All ep-JPHs were able to scavenge DPPH radicals. Thus, jellyfish protein hydrolysate may be used in functional food applications due to its antioxidant ability. However, \%inhibition of DPPH radical of ep-JPH was lower when compared with other studies. Therefore, further studies on ep-JPH conditions, such as an increase enzyme concentration, different hydrolysis times, and temperature are needed to offer the higher bioactivity of ep-JPH. The results of this study lead to an added value of salted jellyfish by-products and reduce waste from the salted jellyfish industry.

\section{Acknowledgement}

This research was financially supported by the KMUTNBNSTDA High Performance Post Graduate Scholarship in Science and Technology (Contract no. B.020-2563) and the National Research Council of Thailand through the NRCT Senior Research Scholar Program (Contract no. 814-2020). In addition, the authors would like to thank Ms.Wanlee Muensawat, managing director of Chockdee Sea Products Co., 
Ltd., Samut Songkhram, Thailand, for supporting salted jellyfish and the jellyfish washing machine used in this study.

\section{References}

1. S. Severin, W.S. Xia, Enzymatic hydrolysis of whey proteins by two different proteases and their effect on the functional properties of resulting protein hydrolysates, Journal of Food Biochemistry, 30, 1 (2006): 77-97

2. T. Julmanlik, S. Kongruang, Functional properties and applications of egg white protein hydrolysates, Journal of Food Technology, Siam University, 14, 1 (2019): 69-87

3. K.M.I. Bashir, J.H. Sohn, J.S. Kim, J.S. Choi, Identification and characterization of novel antioxidant peptides from mackerel (Scomber japonicus) muscle protein hydrolysates, Food Chemistry, 323 (2020): 126809

4. P. Ambigaipalan, F. Shahidi, Bioactive peptides from shrimp shell processing discards: Antioxidant and biological activities, Journal of Functional Foods, 34 (2017): 7-17

5. N. Ktari, R.B.S.B. Salem, I. Bkhairia, S.B. Slima, R. Nasri, R.B. Salah, M. Nasri, Functional properties and biological activities of peptides from zebra blenny protein hydrolysates fractionated using ultrafiltration, Food Bioscience, 34 (2020): 100539

6. S. Silaprueng, B. Thumthanaruk, P. Wongsa-ngasri, Comparative functional properties of jellyfish (Lobonema smithii) protein hydrolysate as influenced by bromelain and hydrochloric acid, Journal of Food Science and Agricultural Technology, 1 (2015): 171-176

7. G. Guillén, M.E. López Caballero, A. Alemán, A.L.D. Lacey, B. Giménez, P. Montero García, in Sea by-Products as Real Material: New Ways of Application, edited by E.L. Bihan (Transworld Research Network, Trivandrum, 2010) pp. 89-115

8. Z. Barzideh, A.A. Latiff, C.Y. Gan, M. Abedin, A.K. Alias, ACE inhibitory and antioxidant activities of collagen hydrolysates from the ribbon jellyfish (Chrysaora sp.). Food Technology and Biotechnology, 52, 4 (2014): 495-504

9. L. Mora, M. Reig, F. Toldrá, Bioactive peptides generated from meat industry by-products, Food Research International, 65 (2014): 344-349

10. T. Sayd, C. Dufour, C. Chambon, C. Buffière, D. Remond, V. Sante-Lhoutellier, Combined in vivo and in silico approaches for predicting the release of bioactive peptides from meat digestion, Food Chemistry, 249 (2018): 111-118

11. F. Tonolo, A. Folda, L. Cesaro, V. Scalcon, O. Marin, S. Ferro, A. Bindoli, M.P. Rigobello, Milkderived bioactive peptides exhibit antioxidant activity through the Keap1-Nrf2 signaling pathway, Journal of Functional Foods, 64 (2020): 103696

12. M. Amorim, J.O. Pereira, L.B. Silva, R.C.S.C. Ormenese, M.T.B. Pacheco, M. Pintado, M., Use of whey peptide fraction in coated cashew nut as functional ingredient and salt replacer, Lebensmittel-Wissenschaft \& Technologie, 92 (2018): 204-211

13. C. Zhao, T.J. Ashaolu, Bioactivity and safety of whey peptides, Lebensmittel-Wissenschaft \& Technologie, 134 (2020): 109935

14. J. Zheng, T. Bu, L. Liu, G. He, S. Li, J. Wu, Naturally occurring low molecular peptides identified in egg white show antioxidant activity, Food Research International, 138 (2020): 109766

15. S. Moreno-Fernández, M. Garcés-Rimón, $M$. Miguel, Egg-derived peptides and hydrolysates: a new bioactive treasure for cardiometabolic diseases, Trends in Food Science \& Technology, 104 (2020): 208-218

16. J. Sealey-Voyksner, J. Zweigenbaum, R. Voyksner, Discovery of highly conserved unique peanut and tree nut peptides by LC-MS/MS for multi-allergen detection, Food Chemistry, 194 (2016): 201-211

17. L.A. Domínguez-Pérez, L.M. Beltrán-Barrientos, A.F. González-Córdova, A. Hernández-Mendoza, B. Vallejo-Cordoba, Artisanal cocoa bean fermentation: From cocoa bean proteins to bioactive peptides with potential health benefits, Journal of Functional Foods, 73 (2020): 104134

18. S. Martini, A. Conte, D. Tagliazucchi, Comparative profile and bioactivities of cooked beef, pork, chicken and turkey meat after In vitro gastrointestinal digestion, Journal of Proteomics, 208 (2019): 1-10

19. A. Cerrato, A.L. Capriotti, F. Capuano, C. Cavaliere, A.M.I. Montone, C.M. Montone, S. Piovesana, Z. Chiozzi, A. Laganà, Identification and antimicrobial activity of medium-sized and short peptides from yellowfin tuna (Thunnus albacares) simulated gastrointestinal digestion, Foods, 9 (2020): 1-12

20. H. Korhonen, A. Pihlanto, Bioactive peptides: production and functionality, International Dairy Journal, 16, 9 (2006): 945-960

21. K. Fields, T.J. Falla, K. Rodan, L. Bush, Bioactive peptides: signaling the future, Journal of Cosmetic Dermatology, 8, 1 (2009): 8-13

22. E. Maestri, M. Marmiroli, N. Marmiroli, Bioactive peptides in plant-derived foodstuffs, Journal of Proteomics, 147 (2016): 140-155

23. H.M. Rawel, G. Huschek, S.T. Sagu, T. Homann, Cocoa bean proteins-characterization, changes and modifications due to ripening and post-harvest processing, Nutrients, 11, 2 (2019): 428

24. Y.L. Zhuang, X. Zhao, B.F. Li, Optimization of antioxidant activity by response surface methodology in hydrolysates of jellyfish (Rhopilema esculentum) umbrella collagen, Journal of Zhejiang University Science B, 10, 8 (2009): 572-579

25. B. Li, F. Chen, X. Wang, B. Ji, Y. Wu, Isolation and identification of antioxidative peptides from porcine 
collagen hydrolysate by consecutive chromatography and electrospray ionization-mass spectrometry, Food Chemistry, 102, 4 (2007): 11351143

26. P. Khositanon, N. Panya, S. Roytrakul, S Krobthong, S. Chanroj, W. Choksawangkarn, Effects of fermentation periods on antioxidant and angiotensin I-converting enzyme inhibitory activities of peptides from fish sauce by-products, Lebensmittel-Wissenschaft \& Technologie, 135 (2021): 110122

27. P. Muangrod, V. Rungsardthong, S. Vatanyoopaisarn, Y. Tamaki, E. Kuraya, B. Thumthanaruk, Effect of wash cycle on physical and chemical properties of rehydrated jellyfish byproducts and jellyfish protein powder, Science, Engineering and Health Studies, 15 (2021): 21030004-21030004

28. Y.H.P. Hsieh, F.M. Leong, J. Rudloe, Jellyfish as food, Hydrobiologia, 451 (2001): 11-17

29. W. Charoenchokpanich, V. Rungsardthong, S. Vatanyoopaisarn, B. Thumthanaruk, Y. Tamaki, Salt reduction in salted jellyfish (Lobonema smithii) using a mechanical washing machine, Science, Engineering and Health Studies, 14 (2020): 184-192

30. C.F. Chi, F.Y. Hu, B. Wang, X.J. Ren, S.G. Deng, C.W. Wu, Purification and characterization of three antioxidant peptides from protein hydrolyzate of croceine croaker (Pseudosciaena crocea) muscle, Food Chemistry, 168 (2015): 662-667

31. K.O. Lima, C.D.C.D. Quadros, M.D. Rocha, J.T.J.G.D. Lacerda, M.A. Juliano, M. Dias, M.A. Mendes, C. Prentice, Bioactivity and bioaccessibility of protein hydrolyzates from industrial byproducts of Stripped weakfish (Cynoscion guatucupa), Lebensmittel-Wissenschaft \& Technologie, 111 (2019): 408-413

32. AOAC, Official Methods of Analysis of AOAC International (AOAC International, Maryland, USA, 2000)

33. C.S. James, Analytical Chemistry of Foods (Springer, London, 1995)

34. O.H. Lowry, N.J. Rosebrough, A.L. Farr, R.J. Randall, Protein measurement with the Folin phenol reagent, Journal of Biological Chemistry, 193 (1951): 265-275

35. S. Benjakul, M.T. Morrissey, Protein hydrolysates from Pacific whiting solid wastes, Journal of Agricultural and Food Chemistry, 45, 9 (1997): 3423-3430

36. P. Molyneux, The use of stable free radical diphenylpicrylhydrazyl (DPPH) for estimating antioxidant activity, Songklanakarin Journal of Science and Technology, 26 (2004): 211-219

37. T. Emrerk, V. Rungsardthong, S. Vatanyoopaisarn, B. Thumthanaruk, Y. Tamaki, E. Kuraya, Processed flavors derived from combined bromelain hydrolyzed jellyfish protein hydrolysate, reducing sugars and arginine, Science, Engineering and Health Studies, 15 (2021): 21030002-21030002

38. I. Batish, D. Brits, P. Valencia, C. Miyai, S. Rafeeq, Y. Xu, M. Galanopoulos, E. Sismour, R. Ovissipour, Effects of enzymatic hydrolysis on the functional properties, antioxidant activity and protein structure of black soldier fly (Hermetia illucens) protein, Insects, 11, 876 (2020): 1-12 